\title{
MEMBANGUN KESADARAN BERPERILAKU SISWA MADRASAH DENGAN PENGUATAN NILAI-NILAI SPIRITUAL
}

\author{
Sulthon \\ STAIN Kudus, Jawa Tengah, Indonesia \\ sulthon52@gmail.com
}

\begin{abstract}
Abstrak
Usia siswa di tingkat madrasah merupakan fase usia pendidikan dimana siswa masih memiliki sifat ketergantung pada otoritas orang dewasa dalam proses perkembangannya. Siswa sebagai seorang manusia pada hakekatnya memiliki fitrah yang baik dan selalu ingin berbuat baik. Namun, dalam hidup terkadang mereka menghadapi berbagai tantangan dan hambatan yang mempengaruhinya dalam berperilaku. Penguatan nilai-nilai spiritual menjadi penting dalam upaya untuk memproteksi pribadi siswa menuju terbentuknya karakter positif. Tujuan kajian ini selain untuk mengetahui bagaimana membangun kesadaran berperilaku siswa Madrasah Ibtidaiyah melalui pengukuhan spiritual, juga untuk mengetahui langkah-langkah dalam membangun kesadaran berperilaku siswa. Metode dalam kajian ini lebih terfokus pada kajian library reaserch dimana peneliti menelusuri literatur-literatur yang membahas tentang kesadaran berperilaku dan spiritualisme dalam membangun kesadaran perilaku siswa melalui pengukuhan spiritualisme siswa di MI. Hasil kajian ini mengarah pada pembahasan bagaimana perilaku siswa banyak dipengaruhi oleh keadaan jiwa dan spiritualitas seseorang.
\end{abstract}

Kata Kunci: Kesadaran Berperilaku, Penguatan, Nilai-nilai Spiritual. 


\begin{abstract}
BUILDING BEHAVIOR AWARENESS OF MADRASAH STUDENTS BY STRENGTHENING THE SPIRITUAL VALUES. The age of the students at the madrasah level is in the education age phase where in their development, they are still dependent on the adults. Students as human essentially have good nature and always want to do the good things. However, sometimes they face a variety of challenges and barriers that affect their behaviors. Strengthening spiritual values is important to protect the students' character towards the formation of positive character. The purposes of this study are knowing how to build awareness of the Madrasah Ibtidaiyah students to behave through the inaugural spiritual and finding out the steps in building students' awareness to behave. This study was focused on library research which researchers tried to find some literatures that discuss the behavior consciousness and spiritualism in building students' behavior awareness through spiritualism reinforcement of students in Madrasah Ibtidaiyah. The results of the study lead to a discussion about how students' behavior is much influenced by someone's soul and spirituality.
\end{abstract}

Keywords: behavior awareness, strengthening, spiritual values

\title{
A. Pendahuluan
}

Melihat perilaku dan pergaulan siswa-siswi di madrasah saat ini sangat memprihatinkan. Siswa sudah tidak lagi memiliki kepekaan, rasa malu, dan rasa hormat pada guru, banyak perilaku yang ditampilkan juga kurang sesuai dengan norma dan etika yang seharusnya dijunjung tinggi, disamping itu, ketekunan dan kesungguhan dalam pembelajaran di kelas tampaknya juga menjadi masalah tersendiri bagi guru.

Perkembangan ilmu pengetahuan dan teknologi telah membawa perubahan pola dan budaya dalam hidup menjadi konsumtif dan hedonis. Manusia tidak lagi mau mengalami proses dalam hidup namun cenderung mencari pola yang instan dan tidak mau menjalani proses yang sesungguhnya. Pada hakikatnya hidup merupakan proses yang harus dijalani, dan didalam proses akan terdapat pengalaman hidup yang sangat berarti dalam mempersiapkan menjangkau hidup ke depan, setidaknya pengalaman hidup yang dilakukan itu akan mematangkan kejiwaannya. 
Kemajuan zaman harus tetap kita usahakan, peradaban manusia yang modern sangat kita butuhkan karena dengan peradaban yang maju akan meningkatkan pola dan taraf hidup yang maju pula. Namun yang tidak boleh hilang adalah adatistiadat, budaya, norma, nilai-nilai luhur yang sangat dibutuhkan dalam kehidupan modern supaya tidak terjadi kemerosotan nilai dan norma yang baik.

Nilai, norma, dan adat-istiadat sesungguhnya terkait dengan perilaku dalam hidup, sehingga kemerosotan nilai, norma, dan adat istiadat berarti berperilaku yang kurang memperhatikan nilai, norma serta adat istiadat atau budaya yang kita miliki. Dengan demikian membangun perilaku yang baik sesuai dengan nilai di atas dapat dilakukan melalui penguatan aspek spiritual siswa sehingga akan terjadi penyadaran dalam diri tentang perilaku yang dilakukan berlandaskan pada keyakinan, semangat, dan tanggung jawab yang bermuara pada Tuhan-Nya.

Penguatan nilai-nilai spiritual sangat penting bagi siswa karena berkaitan dengan agama, agama memiliki kekuatan yang besar dalam jiwa membentuk perilaku seseorang, agama yang dipahami akan diamalkan dalam bentuk tindakan atau perilaku beragama yang didasarkan pada ajaran agama.

Dari latar belakang diatas dapat dirumuskan beberapa rumusan masalah yang ingin dijawab dalam kajian ini sebagai berikut: a) Bagaimana membangun kesadaran berperilaku melalui pengukuhan spiritual siswa madrasah?, b) Bagaimana langkahlangkah dalam membangun kesadaran perilaku siswa madrasah melalui pengukuhan spiritual?

Untuk menjawab rumusan masalah diatas, dalam kajian penelitian ini menggunakan metode penelitian pustaka dimana penelitian ini menelaah beberapa literatur yang membahas tentang perilaku dan spiritualisme. Kemudian dari beberapa literatur dijadikan pembanding dan analisis untuk menguatkan pembahasan dalam tulisan ini. Banyak literatur yang membahas tentang perilaku kemudian dijadikan sebagai bahasan yang akhirnya disimpulkan dan dijadikan pertimbangan dalam menentukan pembahasan hubungan dengan pengukuhan berdasarkan spiritualisme. 


\section{B. Pembahasan}

\section{Perilaku dan Penguatan Spiritual Siswa Madrasah}

Sebelum pengertian membahas pengertain perilaku terlebih dahulu akan dijelaskan pengertian sikap, komponen sikap, dan pembentukan sikap karena perilaku selalu didahului dengan adanya sikap.

\section{a. Pengertian Sikap}

Sikap merupakan suatu keadaan yang ada dalam diri seseorang yang menyebabkan terjadinya suatu perilaku. Tri Dayakisni \& Hudaniah (2012:79) mengatakan bahwa sikap merupakan kecenderungan untuk bertindak untuk bereaksi terhadap rangsangan, oleh karena itu manifestasi sikap tidak dapat langsung dilihat akan tetapi harus ditafsirkan terlebih dahulu sebagai tingkah laku yang masih tertutup. Sikap akan selalu diikuti dengan perilaku, sikap sebagai suatu penilaian untuk menolak, menyetujui, atau menerima selanjutnya akan diikuti dengan perilaku tertentu. Sebagai contoh jika seseorang menyetujui adanya larangan merokok dalam kelas, maka seseorang tersebut pastinya akan mendukung aturan tersebut dan tidak akan merokok dalam kelas.

\section{b. Komponen Sikap}

Sikap sebagai hubungan yang saling keterkaitan dengan perilaku maka sesungguhnya sikap itu memiliki komponenkomponen yang setidaknya ada tiga yaitu komponen kognitif, komponen afektif, dan komponen konatif. Komponen kognitif berkaitan dengan pemahaman dan pengetahuan tentang obyek yang dimiliki seseorang sedang komponen afektif adalah komponen yang berkaitan dengan rasa senang atau tidak senang, hal ini sebagai bahan evaluasi tentang sistem nilai yang diamati. Komponen konatif merupakan komponen terakhir yang berhubungan dengan perilaku sebagai hubungan dengan obyek sikapnya (Tri Dayakisni, 2012:80).

Dalam bersikap setidaknya dimulai dengan pengetahuan atau pemahaman berkaitan dengan apa yang sedang diperhatikan tentang obyek, selanjutnya diadakan penilaian tentang obyek 
disertai dengan rasa menerima atau menolak, bila nilai tersebut sesuai dan diterima maka langkah berikutnya adalah berperilaku atau bertindak sesuai dengan yang disetujui tersebut.

Setiap terjadinya sebuah perilaku selalu didahului urutanya dari ketiga aspek tersebut secara beraturan dimulai dari kognitif, kemudian afektif, dan konatif begitu seterusnya.

\section{c. Pembentukan Sikap}

Sikap yang dimiliki individu sebenarnya tidak terbentuk dengan sendirinya namun banyak dipengaruhi dari dalam diri, lingkungan, dan pengalaman hidupnya. Sikap akan berubah sesuai dengan pengaruh yang ada terutama lingkungan sangat berpotensi besar terhadap pembentukan sikap ini, baik melalui interaksi, budaya, nilai-nilai, norma, dan sebagainya. Sikap akan berubah sepanjang waktu sesuai dengan pengaruh dan pengalaman yang dimiliki seseorang.

Bimo Walgito mengatkan bahwa pembentukan dan perubahan sikap akan ditentukan oleh dua faktor, yaitu: 1) faktor internal (individu sendiri), yaitu cara individu dalam menanggapi dunia luar dengan selektif sehingga tidak semua yang datang akan diterima atau ditolak; 2) faktor eksternal, yaiu keadaan-keadaan yang ada di luar individu yang merupakan stimulus untuk membentuk atau mengubah sikap (Walgito, 1980:31).

Jadi sikap yang ditampilkan seseorang bisa karena obyek sikap itu sudah dipahami atau diketahui individu tersebut karena pengalaman yang dimiliki atau juga kadang karena pengaruh dari lingkungan, atau bisa juga karena budaya yang sudah disepakati bersama. Secara kuantitas dalam perkembanganya sikap ini akan berubah berdasarkan pola kognitif atau terdapat pengaruh dari lingkungan yang sudah terbentuk.

Berdasarkan proses-proses terbentuknya sikap di atas setidaknya dapat dijadikan suatu dasar untuk membentuk perilaku seseorang, karena perilaku yang ditampilkan seseorang sebenarnya merupakan proses lanjutan dari adanya sikap tersebut. Seorang siswa yang memiliki sikap negatif atau menolak terhadap guru maka perilaku selanjutnya siswa tersebut akan malas dan bahkan tidak mau mengikuti pembelajaran yang diberikan oleh guru. 
Siswa yang tidak suka mata pelajaran matematika misalnya karena memiliki pengalaman kurang menyenangkan dengan nilai matematika yang diperoleh maka sikap yang terbentuk adalah menolak mata pelajaran tersebut dalam kognitifnya sehingga perilaku yang ditampilkan adalah menentang guru atau tidak menghiraukan atau meninggalkan mata pelajaran dengan berbagai alasan. Oleh karenanya maka sikap tersebut harus dirubah dengan mengubah persepsinya yang negatif terhadap guru dan mata pelajaran matematika agar terbentuk sikap dan perilaku yang positif terhadap matematika.

\section{d. Pengertian Perilaku}

Perilaku merupakan sebuah kegiatan yang sistematis teratur dalam hal perasaan (afeksi), pemikiran (kognisi), dan predisposisi tindakan (konasi) seseorang terhadap suatu aspek di lingkungan sekitarnya. Dalam pengertian umum perilaku adalah segala aktifitas perbuatan dan tindakan yang dilakukan makhluk hidup.

Perilaku merupakan sebuah tindakan atau aktivitas dari individu sebagai sebuah aksi atau reaksi terhadap sesuatu yang terjadi pada diri individu tersebut. Perilaku memiliki cakupan yang luas seperti: tersenyum, berjalan, berbicara, menangis, tertawa, bekerja, menulis, membaca, dan sebagainya. Bisa disimpulkan bahwa perilaku manusia adalah segala kegiatan atau aktivitas individu mulai dari aktivitas yang bisa diinderawi ataupun yang tidak dapat diindera.

Perilaku dalam pandangan biologis merupakan suatu kegiatan atau aktivitas organisme yang bersangkutan. Jadi perilaku manusia pada hakekatnya adalah suatu aktivitas dari manusia itu sendiri (Wawan dan Dewi, 2011:50). Perilaku dapat dimaknai sebagai kegitan badaniah maupun ruhaniah manusia dalam rangka merespon atau mencapai sesuatu yang diinginkan. Ketika manusia berjalan ke utara misalnya maka sesungguhnya gerakan anggota tubuh untuk berjalan tersebut sebenarnya merupakan perilaku yang bertujuan misalnya ke utara mau ke toko berarti tujuan perilaku ke toko membeli kebutuhan tertentu. Dengan demikian perilaku yang dilakukan manusia selalu membawa tujuan yang dinginkan. 
Perilaku manusia dapat berupa gerakan tubuh atau fisik dan juga bisa berupa aktivitas jiwa seperti berpikir, mengingatingat, berfantasi dan sebagainya. Semuanya termasuk perilaku. Dalam perilaku sebenarnya selalu berkaitan antara gerakan tubuh dan aktivitas jiwa melalui kegiatan pikiran manusia, apa yang akan dilakukan manusia sesungguhnya selalu didahului atau dipikirkan apa akibatnya dari perilaku itu dan sebagainya. Jadi perilaku yang didasari oleh pemikiran terlebih dahulu maka perilaku tersebut menjadi perilaku yang rasionional, perilaku yang demikian adalah perilaku yang dapat diterima secara rasional oleh semua orang.

\section{e. Proses Pembentukan Perilaku}

Perilaku itu muncul lebih banyak karena adanya setimulus yang datang dari lingkungan sekitar, maka perilaku itu sebenarnya dapat dibentuk oleh lingkungan. Skiner mengatakan bahwa prosedur pembentukan perilaku merupakan hasil hubungan antara perangsang (stimulus) dan tanggapan (respon), sedang respon dalam pandangan Skinner dibedakan menjadi dua yaitu reflexive respons dan operant respons. Reflexive respons merupakan respon yang ditimbulkan oleh rangsangan-rangsangan tertentu seperti respon karena ada buah segar dengan keluar air liur, respon terhadap orang meninggal hingga keluar air mata dan sebagainya. Respon tersebut merupakan reflek manusia karena stimulus bersifat eliciting stimuli dimana respon tersebut bersifat menetap.

Sedang operant respons merupakan respon yang timbul dan berkembangnya diikuti oleh perangsang tertentu, perangsang tersebut memperkuat respons yang telah dilakukan oleh organisme, respon tersebut memperkuat perilaku (Wawan dan Dewi, 2011:50). Respon yang demikian dapat lebih diperkuat dan dibentuk sesuai dengan keinginan karena respon yang timbul mengikuti dinamika penguatnya, jika anak diberikan hadiah saat anak menunjukkan keberhasilan maka anak akan semakin giat lagi dalam berusaha untuk belajar karena kuatnya keinginan untuk mendapatkan penghargaan begitu seterusnya, namun dalam memberikan hadiah tersebut harus memperhatikan urutan respon tertentu. 
Dalam proses terbentuknya perilaku manusia banyak ditentukan oleh operant respons. Sedang dalam membentuk jenis perilaku ini perlu diciptakan suatu kondisi yaitu sebagai berikut:

1. Melakukan identifikasi tentang hal yang merupakan penguat perilaku yang akan dibentuk;

2. Melakukan analisis untuk mengidentifikasi komponenkomponen kecil yang membentuk perilaku yang dikehendaki;

3. Dengan menggunakan secara urut komponen-komponen itu sebagai tujuan-tujuan sementara, mengidentifikasi reinforcer;

4. Melakukan pembentukan perilaku dengan menggunakan urutan komponen yang telah tersusun itu (Wawan dan Dewi, 2011:52).

Dalam pembentukan perilaku, pertama harus dilakukan identifikasi hal yang menjadi penguat yang berupa hadiah bagi perilaku yang akan dibentuk, kemudian menganalisis terjadinya perubahan perilaku yang dibentuk dengan urutan komponen yang membentuk perilaku.

Terkait dengan terbentuknya perilaku manusia, terdapat pendapat yang berbeda bahwa munculnya perilaku manusia banyak ditentukan oleh beberapa hal diantaranya berdasarkan sifatnya yang intrinsik, maka munculnya motivasi berperilaku sebagai akibat dari tiga hal yaitu kebutuhan, pengetahuan, dan aspirasi cita-cita. Sedang motivasi munculnya perilaku yang ekstrinsik juga dipengaruhi oleh tiga hal yaitu, ganjaran, hukuman, dan persaingan atau kompetisi (Baharuddin, 2004:239). Manusia dalam berperilaku sebenarnya memiliki motif yang berbedabeda sehingga sulit untuk dipahami secara jelas. Oleh karenanya dibutuhkan studi yang mendalam tentang munculnya perilaku tersebut. Dalam bahasan ini akan dikerucutkan pada timbulnya perilaku karena kebutuhan ruhaniah yang merupakan kebutuhan yang bersifat spiritual dimana di dalamnya terdapat kebutuhan perwujudan diri dan kebutuhan ibadah (agama) (Baharuddin, 2004:239). 
Manusia pada hakikatnya memiliki kesadaran bahwa keberadaanya di dunia ini memiliki tugas sebagai kholifah di bumi, yaitu menjaga, memelihara, merawat, dan melindungi alam ini dengan penuh tanggung jawab. Dalam menjalankan tugas keKholifahan ini manusia ditunjang dengan potensi yang dimiliki. Potensi ini akan berkembang sesuai dengan perkembangan jiwa manusia. Sedang kebutuhan ibadah merupakan kebutuhan yang bersifat fitrah, sifat fitrah ini bersumber dari kebutuhan akan agama yang wujudnya adalah ibadah sebagai tugas manusia.

Ibadah memiliki makna yang luas tidak hanya yang bersifat ritual seperti sholat, puasa, haji dan seterusnya namun segala perbuatan yang dilakukan dengan niat untuk mencapai keridloan Allah semua itu adalah ibadah. Berdasarkan pemahaman ibadah tersebut maka sesungguhnya tugas manusia sebagai kholifah di bumi ini sesungguhnya merupakan bagian dari ibadah kepada Allah.

Ibnu Qoyyim mengatakan bahwa ibadah menuntut dua dasar utama , yang pertama kecintaan dan yang kedua kerendahan diri dan ketundukan. Bila mengatakan cinta Allah namun tidak tunduk kepada-Nya maka belum dikatakan hamba yang beribadah kepada-Nya, sedang tunduk kepada-Nya namun tidak mencintainya maka juga belum dikatakan sebagai hamba-Nya, dan seseorang akan benar-benar menjadi hamba Allah jika dia telah memadukan dalam dirinya antara kecintaan dan ketundukan kepada-Nya (Baharuddin, 2004:239).

Dengan demikian dapat dijelaskan bahwa perilaku manusia dalam proses terbentuknya dapat dipengaruhi oleh beberapa hal diantaranya; 1 ) adanya stimulus dan respon yang terbentuk dari lingkungan dan 2) adanya motivasi berperilaku, disisni motivasi berperilaku bisa dari dalam diri (intrinsik) yang berupa kebutuhan, pengetahuan, dan aspirasi cita-cita, dan perilaku yang ekstrinsik yaitu, ganjaran, hukuman, dan persaingan atau kompetisi.

Semua hal di atas baik stimulus-respon maupun motivasi semuanya menyebabkan timbulnya perilaku. Jika dicermati secara mendalam perilaku manusia yang ditimbulkan itu sebenarnya tidak lepas dari adanya keinginan-keinginan manusia baik yang bersifat biologis maupun yang bersifat psikologis. Keinginan 
yang bersifat biologis lebih berhubungan dengan kebutuhan mempertahankan hidupnya sedang keinginan yang bersifat psikologis lebih banyak berkaitan dengan eksisitensi manusia dalam hidupnya, bagaimana hubungan dengan Tuhannya, sesama manusia, dan hubungan dengan alam.

Dengan demikian perilaku manusia harus selalu diarahkan dan dibimbing agar tidak terjadi kecenderungan salah satunya antara kedua kebutuhan tersebut, namun harus diupayakan secara seimbang. Kebutuhan biologis itu penting karena agar tetap hidup manusia butuh makan dan minum serta lainya dalam hidup namun tidak berhenti di sini, kebutuhan psikologis jauh lebih penting seperti kebutuhan ketenangan, ketentraman, beribadah, dan semua aktivitas jiwa manusia dalam rangka menghambakan diri pada Allah sesungguhnya merupakan perilaku manusia yang harus dibina dan dibiasakan agar tetap lestari dan seimbang.

\section{Perilaku Beragama}

Perilaku yang ditampilkan seseorang sesungguhnya adalah ekspresi dari kehidupan jiwanya. Perilaku sangat dipengaruhi oleh situasi kehidupan jiwanya saat itu, oleh karena itu maka perilaku manusia dapat dibentuk dan dikembangkan dalam suasana kehidupan jiwanya itu.

Perilaku secara umum dapat ditinjau dari dua aspek yaitu aspek sosial dan aspek intrapsikis, ditinjau dari sosial perilaku merupakan pengaruh hubungan antara organisme dengan lingkunagan. Sedang secara intrapsikis adalah proses-proses dan dinamika psikologis yang mendasari perilaku (Irwanto, 2002:21). Perilaku yang muncul sesungguhnya dapat berasal dari adanya stimulus dari lingkungan yang kemudian individu harus memberikan respon atas stimulus tersebut. Seperti contoh saat seseorang diketuk pintunya dan ada orang mau minta tolong maka perilaku keluar dan menolong adalah perilaku interaksi dari lingkungan.

Namun ada juga perilaku yang muncul akibat dari adanya dorongan dari dalam seperti adanya keinginan-keinginan terhadap sesuatu yang harus dipenuhi misalnya keinginan untuk beli pulsa, jajan, beli buku, ingin belajar dan sebagainya. Perilaku 
yang demikian timbul dari dinamika psikis individu yang muncul secara individu.

Dalam perilaku yang disebabkan oleh adanya interaksi sosial akan selalu dimulai dari adanya sikap-sikap tertentu yang mendahului terbentuknya perilaku. Secara definisi sikap adalah kecenderungan untuk bertindak untuk beraksi terhadap rangsangan. Oleh karena itu manifestasi sikap tidak dapat langsung dilihat akan tetapi harus ditafsirkan terlebih dahulu sebagai perilaku yang masih tertutup (Irwanto, 2002:79).

Dalam aliran perlaku atau behaviorisme oleh B.F. Skinner berpendapat bahwa perilaku manusia pada umumnya dapat dijelaskan berdasarkan teori pengkondisian operan (operant conditioning). Manusia berbuat sesuatu dalam lingkungannya untuk mendatangkan akibat-akibat entah untuk mendatangkan pemenuhan kebutuhan atau menghindari datangnya hukuman atau pengalaman yang tidak enak (Djamaludin Ancok \& Fuat Nashori Suroso, 19954: 72). Dalam aliran perilaku ini bahwa pada prinsipnya manusia melakukan suatu perbuatan atau tindakan selalu dimotori oleh keinginan pokok manusia yaitu ingin memenuhi kebutuhan hidupnya dan berusaha untuk menghindari hal yang tidak menyenagkan dalam hidupnya.

Watson sebagai tokoh Behaviorisme mengemukakan bahwa asumsi dasar mengenai tingkah laku sepenuhnya ditentukan oleh aturan-aturan, bisa diramalkan, dan bisa dikendalikan. Gagasan teori ini adalah bahwa untuk memahami perilaku dibutuhkan pendekatan yang obyektif, mekanistik, dan materialistik sehingga perubahan tingkah laku pada diri seseorang dapat dilakukan melalui upaya pengkondisian (Muh Farozin \& Fathiyah, 2004: 72).

Perilaku yang ditampilkan individu itu selalu berubahrubah sesuai dengan obyek perilaku itu sendiri sehingga perilaku tertentu yang dilakukan individu itu bersumber dari keinginan untuk mendapatkan hal yang menyenangkan dan juga bisa terjadi karena tidak ingin memperoleh hal yang tidak diinginkan atau bahkan perilaku yang dilakukan itu semata-mata karena mengalir saja tanpa adanya muatan tertentu. 
Perilaku-perilaku tertentu yang selalu dilakukan oleh individu secara terus-menerus maka akan menjadi ciri khas individu tersebut sehingga menjadi karakter individu tersebut, sebagai contoh perilaku marah atau emosi, jika individu setiap menghadapi masalah yang kurang menyenangkan dia responya adalah marah atau emosi, maka individu tersebut akan dikategorikan sebagai orang emosional. Jika seseorang yang selalu memiliki sikap rendah diri, suka menolong pada orang lemah, peka dalam kehidupan sosial dan dilakukan secara terus-menerus maka orang tersebut akan dijuluki manusia sosial atau orang baikan dan seterusnya.

Dalam konteks perilaku manusia beragama, sesungguhnya tidak dapat diukur dari keinginan untuk memenuhi kebutuhan dan menghindari hukuman namun adanya kekuatan dalam diri yang berkaitan dengan tanggung jawab untuk mendekatkan diri kepada Allah sebagai tugas utama manusia pada Tuhan-Nya. Jika ditelusuri lebih dalam sesungguhnya adanya keinginan untuk beribadah kepada Allah karena tidak ingin mendapatkan siksa atau suatu yang tidak menyenangkan, hanya saja kekuatan untuk menghindar dari hal tersebut karena diyakini sebagai ajaran agama yang harus diamalkan.

Perilaku beragama tidak hanya menyangkut ritual ibadah namun menjangkau sampai hal yang tidak tampak oleh kasat mata, oleh karenanya perilaku beragama menjangkau berbagai sisi dan dimensi. Artinya bahwa dalam hal aktivitas beribadah, termasuk keyakinan-keyakinan untuk berbuat baik, meyakini adanya ajaran Islam tentang hal-hal yang ghoib sehingga menguatkan jiwanya untuk tidak melakukan yang dilarang agama sebenarnya termasuk aktivitas beragama yang tidak tampak.

Glock \& Stark (dalam Djamaludin Ancok \& Fuat Nashori Suroso, 1994: 77-78) mengemukakan ada lima macam dimensi keberagamaan, yaitu dimensi keyakinan (ideologis), dimensi peribadatan atau praktik agama (ritualistik), dimensi penghayatan (eksperiensial), dimensi pengalaman (konsekuensial), dan dimensi pengetahuan agama (intelektual). Perilaku beragama dimulai dari adanya keyakinan seseorang tentang agama yang dianut, keyakinan ini memiliki kekuatan dalam diri untuk 
melakukan apa saja sesuatu yang dianjurkan oleh ajaran agama yang diyakini.

Beragama akan dilanjutkan dengan perilaku beribadah atau praktik agama sebagai manifestasi oleh ajaran agama yang diyakini tersebut. Ketika menjalankan aktivitas beragama maka seseorang akan menghayati dengan sesungguhnya tentang kedekatan dan ingin menyatu dengan Tuhan-Nya. Dengan melaksanakan atau praktikibadah yang sesungguhnya maka akan terdapat pengalaman keagamaan sehingga seseorang akan merasa nyaman, tenang dan bahagia karena adanya kekuatan yang dimiliki seseorang karena pengalaman yang dimiliki dalam beribadah kepada Allah. Dalam hal ini setiap orang memiliki pengalaman yang berbeda tentang beragama tersebut sesuai dengan pengamalan agama yang dianut. Pengetahuan agama merupakan dasar bagi seseorang untuk melakukan aktivitas beragama sesuai dengan agama yang diyakini. Seseorang tidak mungkin bisa melakukan ajaran agama manakala tidak memiliki pengetahuan agama yang dianut.

Berdasarkan lima dimensi keberagamaan di atas sebenarnya dapat dipahami secara sederhana bahwa keyakinan akan agama yang dianut menjadi kemutlakan karena tanpa adanya keyakinan tak akan ada konsekuensi seseorang untuk menjalankan agama, selanjutnya dimensi praktik agama atau peribadatan merupakan tindakan lanjutan setelah meyakini atau mengimani terhadap suatu agama maka melakukan ibadah adalah bagian dari rangkaian pengakuan akan keimanan tersebut.

Dalam kehidupan iman dan ibadah yang dilakukan tentunya akan membentuk keaktifan jiwa dalam merenungi, menghayati dan mempererat hubungan psikologis antara manusia dengan Tuhannya yang selalu diingat, dirasa, dicinta, dan didambakan dalam setiap aktivitas hidupnya untuk menghambakan diri, dengan terbentuknya penghayatan dalam beragama yang mapan maka seseorang secara tidak disadari akan terbentuk suatu kekuatan dalam dirinya untuk selalu melakukan hal-hal yang diperintahkan agama serta terdapat kekuatan untuk meningglakan hal-hal yang dilarang agama. Kondisi dalam jiwa yang demikian adalah pengalaman beragama yang dimiliki seseorang yang 
termanifestasi dalam kekuatan untuk selalu berbuat baik dalam kehidupan ini.

Dimensi pengetahuan agama sebenarnya merupakan kunci suksesnya perilaku beragama karena beragama adalah sebuah rentetan yang dimulai dari adanya pengetahuan agama, tanpa pengetahuan agama maka sesungguhnya seorang beragama tidak akan sampai pada tujuan, oleh karena itu pengetahuan agama menjadi penopang seseorang dapat beragama secara baik dan kaffah demikian sebaliknya tanpa pengetahuan agama yang mumpuni maka seseorang tak akan dapat beragama secara baik.

\section{Penguatan Spritual}

\section{a. Pengertian Spiritual}

Spiritual adalah suatu keyakinan yang percaya kepada kekuatan yang maha kuasa (Tuhan) di atas segala kemampuan manusia (Sudibyo Ali moeso, 2012: 3). Dalam Kamus Besar Bahasa Indonesia spiritual adalah berhubungan dengan atau bersifat kejiwaan (rohani bathin) (Departemen Pendidikan, 2008:1335). Sedang menurut Kamus Psikologi dikatakan bahwa spiritual adalah pertama, berkaitan dengan roh, semangat atau jiwa, kedua, religius yang berhubungan dengan agama, keimanan, kesalehan, menyangkut nilai-nilai transendental ketiga, sifat mental bersifat lawan dari mental, fisik, atau jasmaniyah (J.P. Chaplin, 2008:253).

Berdasarkan beberapa pendapat di atas dapat disimpulkan bahwa spiritual adalah suatu keyakinan percaya kepada kekuatan yang maha kuasa (Tuhan) dengan religius atau agama, keimanan, kesalehan, menyangkut nilai-nilai transendental. Dalam hal ini spiritual mengandung makna suatu keyakinan yang berhubungan dengan agama yang menyangkut aktivitas hidup dan kehidupan manusia yang disandarkan pada kekuatan Tuhan sebagai hal yang transenden.

Spiritual sebagai bagian terpenting dalam diri seseorang yang bersifat rohani atau mental yang berhubungan dengan bagaimana manusia itu merespon adanya kekuatan di luar manusia yang tercermin dalam pelaksanaan ajaran agama yang diyakini dan 
diamalkan dalam kehidupan dan menjadi muaranya tujuan akhir dalam kehidupan manusia.

Amalan spiritual juga dikenali sebagai amalan kerohanian. Kerohanian menurut al-Ghazali (2000:532) adalah merujuk kepada empat elemen kerohanian manusia yaitu al-ruh, al-qalb, al'aql dan al-nafs. Ini menjelaskan bahawa aspek kerohanian adalah aspek ma'nawi yang tersimpan di dalam diri manusia (Salasiah Hanin Hamjah dkk., 2012:3).

Dengan demikian spiritual yang ada pada manusia akan terwujud dalam suatu amalan ibadah sebagai cerminan dari keyakinan agama yang dianut dalam bentuk melaksanakan hal yang diperintah dan meninggalkan hal-hal yang dilarang agama dalam rangka mencapai keridloaan Allah SWT.

\section{b. Peranan Spiritual dalam Perilaku}

Pembinaan spiritual atau agama memiliki arti penting dalam hidup dan kehidupan manusia, agama memiliki kekuatan yang dahsyat untuk mengendalikan dan mengatur tindakan atau perilaku manusia. Hanya agama yang mampu melindungi manusia dari perilaku yang jahat, menyimpang, dan hilangnya sifat-sifat manusia. Jika manusia berperilaku tidak sesuai dengan akalnya maka sesungguhnya manusia itu sudah tidak menetapi sifat kemanusiaannya.

Karena pentingnya pondasi keagamaan dalam hidup seseorang, maka memberikan pembinaan spiritual pada anak menjadi sangat urgen agar dikemudian hari anak akan menjadi generasi yang baik. Dalam rangka menjadikan anak menjadi baik dengan mengikuti apa yang sudah dilakukan oleh Rasul saat lahirnya Hasan dan Husin yaitu: 1) Mengumandangkan adzan dan iqomah di telinga anak saat lahir karena dengan adzan akan mengusir bisikan setan dan membawa pengaruh dan kesan dalam hati; 2) Berdo'a dan bersyukur kepada Allah atas karunia-Nya; 3 ) Pemberkahan bayi; 4) Memotong rambut dan bersedekah perak seukur dengan berat rambut tersebut; 5) Aqiqah dua kambing bagi anak laki-laki dan satu kambing bagi anak; 6) Memberi nama;

7) Khitan (Khatib Ahmad santhut, 1998:10-4). 
Pendidikan keagamaan yang perlu diusahakan orang tua sebagaimana dikatakan Zakiah Daradjat dalam surat Al-Baqoroh ayat 177 adalah penanaman jiwa takwa yaitu dengan iman kepada Allah, Hari kemudian, Malaikat, Kitab-Kitab, dan NabiNabi kemudian memberikan harta yang dicintai kepada kaum kerabat, anak yatim, orang miskin lalu mendirikan sembahyang, mengeluarkan zakat, menepati janji yang telah dibuat, dan sabar dalam kesempitan (Zakiah Daradjat, 1975: 46).

Jiwa takwa akan terwujud manakala seseorang memiliki keimanan yang kuat sesuai dengan rukun iman yaitu iman kepada Allah, Malaikat, Nabi, Kitab, dan hari Qiamat setelah itu dilanjutkan perilaku untuk memberikan sesuatu yang paling dicintai demi kecintaannya kepada Allah yaitu memberikan hartanya kepada kerabat, anak yatim, fakir miskin dan menepati janji yang dibuat.

Iman sebagaimana tercermin dalam rukun iman sesungguhnya adalah pondasi seseorang untuk dapat berbuat yang baik sesuai dengan tujuan diciptakan manusia itu sendiri yaitu untuk beribadah kepada Allah SWT. Seseorang dapat beribadah dengan baik manakala seseorang tersebut memiliki iman yang kuat, sedang memberikan harta kepada kaum keraabat, anak yatim, dan fakir miskin adalah amal sholeh sebagai manifestasi dari kepekaan sosial yang merupakan hubungan horisontal atau hubungan kemanusiaan.

Iman pada diri seseorang akan tercermin dalam ibadah, selanjutnya ibadah kepada Allah yang sungguh-sungguh karenaNya merupakan media hubungan antara hamba dengan TuhanNya, sedang jika ibadah yang dilakukan hamba sudah menjadi bagian yang tak terpisahkan dalam hidup maka sesungguhnya seseorang tersebut akan terjaga dari perbuatan yang jelek atau maksiat kepada Allah. Kekuatan spiritual pada diri manusia merupakan kekuatannya yang paling besar, paling agung dan paling mampu untuk berhubungan dengan hakikat wujud (Khatib Ahmad Santhut, 1998:98).

Dengan demikian dapat disimpulkan bahwa perilaku manusia bersifat mekanistik tergantung pada kekuatan dalam diri yang dibangun melalui beberapa tahap, pertama dimulai 
dari penguatan iman yang ada dalam diri seseorang. Penanaman nilai-nilai keimanan yang kuat merupakan hal terpenting yang mampu membangkitkan kekuatan untuk berbuat sesuai dengan keimanan yang dimiliki. Kedua ibadah, ibadah merupakan bagian yang tak terpisahkan dari iman seseorang artinya semakin kuat iman seseorang maka akan termanifestasikan dalam wujud ibadah yang kuat pula, demikian sebaliknya bahwa semakin lemah iman seseorang maka semakin mudah seseorang untuk meninggalkan ibadah. Ketiga amal sholeh, dengan iman yang kuat dan ibadah yang baik maka seseorang akan memiliki kekuatan untuk melakukan perbuatan yang baik.

Karena kuatnya hubungan antara spiritual yang dimiliki seseorang dengan timbulnya perilaku, maka untuk membentuk perilaku yang baik pada seseorang dibutuhkan pembinaan spiritual yang baik pula. Artinya kekuatan spiritual akan berperan dalam membingkai perilaku manusia menjadi lebih baik karena semuanya dikendalikan dan dijaga oleh kekuatan agama yang dimiliki yang termanifestasikan dalam aktivitas ibadah sehingga akan menghasilkan perilaku amal soleh.

Mohammmad Shatar menyatakan bahwa pengukuhan kerohanian dan aspek-aspek kerohanian mampu menyumbang pembelajaran berkesan. Ia berhubungan erat dengan aspek psikologi dan mental manusia dalam konteks kebergantungan manusia kepada Allah (Mohammad Shatar Sabran, 2005). Penguatan spiritual ini menjadi urgen karena secara langsung kondisi ini akan memperkuat timbulnya perilaku yang bermuatan pada ketergantungan dengan Tuhannya. Seseorang akan berperilaku apa saja dalam hidupnya karena motivasinya adalah untuk mencari keridloaan Allah sehingga perilaku itu dilakukan semata-mata karena cintanya kepada Tuhannya.

\section{Penguatan Nilai Spiritual pada Siswa Madrasah.}

Nilai spiritual pada siswa perlu dikukuhkan karena nilai spiritual yang dimiliki siswa dapat menjadi pondasi untuk tidak melakukan perbuatan yang dilarang oleh Allah kemudian akan memperbaiki perilakunya dan beramal sholeh. Untuk memperkuat spiritual siswa, menurut Hasan Bin Ali Al-Hijazy 
melalui memperdalam cinta kepada Allah dan ubudiyah kepadaNya di dalam hati.

Sikap-sikap tersebut diantaranya seperti: 1) Menanamkan perasaan bahwa seorang hamba sangat membutuhkan Allah; 2) Menanamkan ilmu bahwa dia hanya memiliki satu hati, jika hati ini telah penuh dengan cinta kepada sesuatu maka tidak ada tempat bagi cinta kepada yang lainya; 3) Menanamkan keimanan dan keyakinan bahwa apa yang dimilikinya adalah milik Allah dan dia menyadari bahwa ia sama sekali bukan pemilik asli atas apa yang ada di bawah kekuasaannya di dunia ini; 4) Beribadah kepada Allah dengan nama-nya yang maha awal, yang maha akhir, yang maha dhohir, dan maha batin; 5) Dengan mengimplementasikan ketinggian Allah secara mutlak dengan dzat-Nya; 6) Menanamkan ma'rifah tentang banyaknya nikmat Allah yang telah diberikan hamba dan besarnya keutamaan dan karunia-Nya dan juga menanamkan kesadaran tentang kelemahannya; 7) Menanamkan keimanan bahwa Allah-lah yang menciptakan semua perbuatannya, dan Dialah yang menanamkan keimanan dalam hatinya; 8) Menanamkan perasaan bahwa dia sangat butuh kepada hidayah Allah dan menanamkan kefakiran kepada-Nya; 9) Memperhatikan do'a-do'a yang mengandung permintaan taufiq kepada Allah dan pembersihan Allah terhadapnya; 10) Menanamkan pengetahuan dan kesadaran atas nikmat-nikmat Allah kepada manusia; 11) Menanamkan ilmu pengetahuan bahwa cinta kepada Allah adalah tuntutan iman (Hasan bin Ali Al-Hijazy, tt).

Pendapat di atas dapat dijelaskan bahwa dalam rangka pembinaan spiritual pada siswa dibutuhkan materi atau isi yang dapat dilakukan oleh siswa sehingga sedikit demi sedikit pengetahuan siswa akan bertambah seiring dengan bertambahan keimanan dan kepercayaannya pada Allah azza wa jalla, yang pertama harus dilakukan pada siswa adalah menanamkan rasa butuh Allah dalam hidupnya sehingga siswa akan selalu merasa dekat dengan Allah. Selain itu siswa juga harus ditanamkan keimanan dan keyakinan bahwa semua yang dimiliki adalah milik Allah kemudian ditanamkan untuk beribadah, menghitung-hitung kenikmatan yang diterimanya, menanamkan pengetahuan dan kesadaran atas nikmat Allah yang diterimanya, dan menanamkan 
ilmu pengetahuan tentang cinta kepada Allah merupakan tuntutan iman.

Dari uraian di atas dapat diperjelas bahwa dalam rangka menanamkan sikap dan perilaku yang mencerminkan nilai-nilai spiritual adalah dengan memberikan pembinaan kepada siswa tentang nilai-nilai spiritual yang dibangun dengan menanamkan nilai bahwa dia butuh Allah dalam hidupnya melalui penguatan keimanan, ibadah, mengangan-angan tentang nikmat Allah yang diterimanya serta membangun pengetahuan dan kesadaran dan cinta kepada Allah.

Ketika manusia sudah menyadari bahwa dia butuh Allah berarti dalam hidupnya terdapat kekuatan yang dahsyat untuk menyatu dengan Tuhannya melalui taat atau rajin ibadah sebagai media untuk mendekatkan dirinya dengan Allah melalui kesadaran dan kepercayaan atas nikmat Allah dan cinta Allah.

Menanamkan nilai-nilai spiritual di atas tidak akan berhasil manakala dalam pelaksanaannya tidak terintegrasi dalam kehidupan nyata dan selalu berusaha untuk taqorrub atau mendekatkan diri pada Allah dengan sepenuh hati atas dasar kesadaran dan cinta kepada sang pencipta.

Madrasah sebagai tempat menyemai pembinaan nilainilai keagamaan pada siswa sebenarnya menjadi bagian yang tak terpisahkan dari kehidupan masyarakat, maka madrasah memiliki tugas dan tanggung jawab dalam memberikan dasar yang kuat pada peserta didik terkait dengan pembinaan agama di madrasah. Mengapa pembinaan agama di madrasah menjadi sangat penting karena fenomena yang muncul adalah bahwa terjadi ketidak seimbangan antara kemajuan ilmu pengetahuan dan teknologi yang menyebabkan majunya peradaban manusia, kemajuan ini manakala tidak diimbangi dengan kekuatan agama maka kemajuan IPTEK dan peradabannya hanya akan melanggengkan timbulnya masalah yang tak terselesaikan karena sifat egoisme manusia berdampak pada timbulnya kerusakan pada alam, perpecahan antar ras, suku dan golongan hanya ingin melanggengkan egonya masing-masing, pertempuran antar ras menjadi sengketa panjang yang tak kunjung selesai dan saling membunuh, berbeda keyakinan harus terjadi pembantaian, tawuran antar pelajar juga 
tak kunjung reda, kekerasan seksual pada anak semakin parah, dan perilaku-perilaku menyimpang lainya akan semakin menjadi, oleh karena itu pendidikan spiritual di madrasah menjadi keharusan.

Banyak yang bisa dilakukan untuk mendasari generasi dengan penguatan agama, karena hanya dengan agama yang kuat itulah seseorang akan terkendali dalam melakukan perbuatan yang kurang baik karena semua yang dilakukan akan selalu dipertimbangkan oleh kekuatan ajaran agama yang diyakininya.

Hal ini sesuai dengan pendapat Syafari Soma seorang dokter spesialis jiwa yang mengatakan bahwa keadaan alami manusia mempunyai hubungan yang erat dengan keadaan akhlaki dan keadaan rohani manusia. Sehingga cara makan-minum mempengaruhi pula keadaan akhlaki dan rohaninya. Jika keadaan alami dipergunakan sesuai dengan bimbingan syariat (agama), maka sebagaimana suatu benda yang dimasukkan ke dalam api maka berubah menjadi api, seperti itu pula semua keadaan itu berubah menjadi nilai akhlaki dan memberi pengaruh yang mendalam sekali pada rohani (Syafari Soma \& Hajaruddin, 2000: 23).

Dengan kata lain untuk membentuk siswa agar menjadi baik, maka siswa harus dibiasakan dan ditempatkan pada tempat yang baik sehingga siswa tersebut akan menjadi baik. Melalui pengetahuan yang dipelajari siswa di sekolah harus dihubungkan dengan kehidupan nyata serta perintah atau anjuran agama. sebagai contoh siswa belajar ilmu pengetahuan alam tentang ekosistem misalnya maka setelah siswa memiliki pengetahuan tentang ekosistem harus dilanjutkan dengan bagaimana siswa harus menjaga dan memelihara ekosistem tersebut dalam kehidupannya, karena menjaga ekosistem tersebut demi menjaga lingkungan hidup manusia, hewan dan makhluk hidup lainya di alam ini. Hal ini harus dihubungkan dengan ajaran agama dalam hal menjaga lingkungan hidup dan harus dibiasakan dalam kehidupan sehari-hari sehingga siswa memiliki perilaku yang baik dan tidak merusaka alam. 


\section{Simpulan}

Demikian uraian singkat tentang membangun kesadaran berperilaku dengan pengukuhan nilai-nilai spiritual siswa di Madrasah yang secara teoritis dan praktis diuraikan bagaimana terbentuknya perilaku manusia dalam setiap aktivitas yang dilakukan dan bagaimana membentuk perilaku agar tetap sesuai dengan sifat-sifat kemanusiaanya.

Perilaku yang ditampilkan manusia selalu memiliki akibatakibat yang diharapkan dalam rangka mencapai sesuatu yang diinginkan. Namun sesuatu yang diinginkan manusia sebagai ekspresi perilaku tersebut tidak selamanya baik atau sesuai dengan nilai, norma atau adat istiadat yang dijunjung tinggi, karena keinginan-keinginan yang dimiliki manusia tadi tidak selalu untuk terpenuhinya kebutuhan fisik dan ruhaninya.

Motivasi berperilaku yang akibatnya untuk terpenuhinya kebutuhan fisik atau biologis dampaknya tidak selalu beriringan dengan kebutuhan lainya seperti kebutuhan ruhani atau psikologis. Namun sebaliknya perilaku yang akibatnya untuk tercapainya kebutuhan ruhani lebih banyak mengarah pada kebaikan dan kesempurnaan manusia.

Menguatkan terbentuknya perilaku yang berorientasi pada terpenuhinya kebutuhan ruhani seperti keinginan untuk selalu beribadah dan mendekatkan diri pada Tuhannya adalah upaya manusia agar tercipta sikap dan perilaku bahkan kepribadian yang agamis dan moralis. 


\section{DAFTAR PUSTAKA}

Baharuddin, Paradigma Psikologi Islam, Yogyakarta: Pustaka Pelajar, 2004.

Djamaludin Ancok \&Fuad Nashori Suroso, Psikologi Islami, Yogyakarta:Pustaka Pelajar, 1994.

Hasan bin Ali Al-Hijazy, Manhaj Tarbiyah Ibnu Qoyyim, tt.

Irwanto. Psikologi Umum, Jakarta: PT. Prenhallindo, 2002.

Khatib Ahmad Santhut, Menumbuhkan Sikap Sosial, Moral dan Spiritual Anak dalam Keluarga Muslim, terj. Ibnu Burdah, Yogyakarta: Mitra Pustaka, 1998.

Mohammad Shatar Sabran. Tujuh Rahsia Kecemerlangan Akademik Kuala Lumpur: Utusan Publications \& Distributors. 2005.

Muh Farozin \& Fathiyah, Pemahaman Tingkah laku, Jakarta: Rieneka Cipta, 2004.

Tri Dayakisni \& Hudaniah, Psikologi Sosial, Malang: UMM Press, 2012.

Walgito, Psikologi Sosial, Yogyakarta: Yayasan Penerbitan Fakultas Psikologi, Universitas Gajah Mada, 1980.

Wawan dan Dewi, Teori dan Pengukuran Pengetahuan, sikap, dan Perilaku Manusia, Yogyakarta: Nuha Medika, 2011. 